\title{
The Development of OTOP Product Packaging Design of Maha Sawat Farmer Housewife Group, Nakhon Pathom Province, Thailand
}

\author{
Wat Ploysri ${ }^{1}$, Krairop Charoensopa ${ }^{1} \&$ Suppawan Pankohlerng ${ }^{1}$ \\ ${ }^{1}$ Printing Industry Department, Faculty of Industrial Technology, Suan Sunandha Rajabhat University, Thailand \\ Correspondence: Wat Ploysri. E-mail: wat.pl@ssru.ac.th
}

Received: July 6, $2018 \quad$ Accepted: July 21, $2018 \quad$ Online Published: August 31, 2018

doi:10.5539/ass.v14n9p111

URL: https://doi.org/10.5539/ass.v14n9p111

\begin{abstract}
The aims of the study were: (1) to investigate the needs toward product packaging of the farmer housewife group in Maha Sawat, Nakhon Pathom province, (2) to develop the product packaging design of the farmer housewife group in Maha Sawat, Nakhon Pathom province, and (3) to test the product-packaging market from consumers of the farmer housewife group in Maha Sawat, Nakhon Pathom province. The sample included (1) ten participants for analyzing needs toward the product packaging by employing the focus group discussion and (2) two-hundred consumers for testing product-packaging market by using a questionaire. The findings elucidated that (1) the farmer housewife group and consumers needed the product packaging to have a capacity to extend shelf life of the snack, to keep and reopen next time, as well as to protect the product while packing. Besides, the packaging should have the beautiful and attractive logo which can represent the group's identity and label which can correctly inform the product description as well as should be compact and portable. (2) The packaging of Thai rice crackers (Kao Tung) made by the farmer housewife group in Maha Sawat had the high level of average assessed by the experts. (3) The market-test result on consumers' satisfaction towards the farmer housewife group's product packaging demonstrated the average with 4.38 and the standard deviation with 0.55 . The market-test result on consumers' satisfaction towards the product packaging based on gender and age showed that all aspects were insignificantly different.
\end{abstract}

Keywords: packaging design, package, OTOP product

\section{Introduction}

The Maha Sawat farmer housewife group is a housewife community conjoining to produce OTOP products. This group was established on 20 October 1977 under the guidance of the Agricultural Extension Officers. The place where they work settled in 8/2, Village No. 3, Saladin village, Maha Sawat sub-district, Phutthamonthon district, Nakhon Pathom province 73170 . The concept of the OTOP products is that each village has its own product by utilizing local materials or resources as well as local wisdom to develop a product of the community in order to make money to the community and local people.

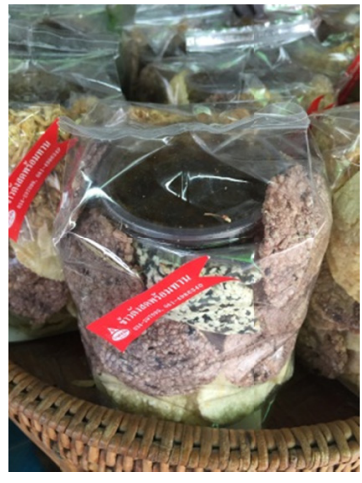

a

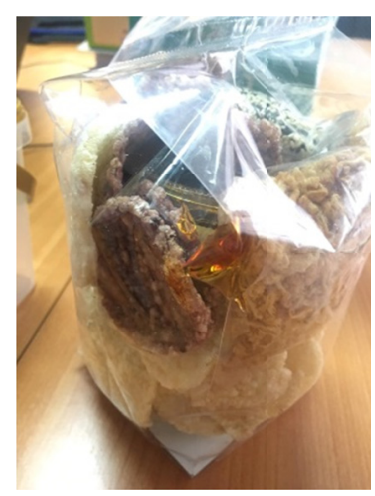

b

Figure 1. The old Kao-Tung packaging of the Maha Sawat farmer housewife group a refers to the old packaging before being developed $b$ refers to the fragility of the old Kao-Tung packaging 
The farmer housewife group in Maha Sawat has processed many agricultural products, and at present, the group mainly produces and sells Thai rice crackers (Kao Tung), the sugar-coated dehydrated fruits, the solar dried bananas and the iodized salted eggs. As observed, the problems and needs of product packaging nowadays normally relate to the shelf-life extension of production processing as well as consumption processing, the outdated shape of packaging which is not consistent with modern-day living, and the fragility of the old Kao-Tung packaging. These aspects entail an inability to increase a product price.

Consequently, it is important to emphasize the product packaging design development of the farmer housewife group in Maha Sawat in order to replace the old packaging. Additionally, the developed product packaging can be also utilized in overcoming the problems as well as raising its price and value. Besides, this is a suitable way to increase an opportunity and income to small and medium enterprises (SMEs) as well as community economy.

According to the Civil-State policy proposed by Thai government led by the Prime Minister General Prayut Chan-ocha, the objectives of the study are to produce (1) the packaging which can protect and expand the shelf life of product and (2) the outstanding and attractive packaging which can promote the product circulation of the Maha Sawat farmer housewife group.

These major roles toward a community enterprise group in developing a product packaging design can offer an increase of sales revenues as well as a decrease of product capital at the same time. For these reasons, it can bring about a higher profit on selling products which is in accordance with a goal of every organization. As seen, consumers at present need to spend less time shopping while there are thousands of the same products available for them to consume. Therefore, it is necessary to develop the product packaging design into the attractive and outstanding version in order to draw more consumers' attention (Sam, 2018) to solve the mentioned problems.

\section{Literature Review}

A product packaging is important since it does not only protect a product form damages during production processing to consumption processing, but its components (i.e., characteristic, color, logo and identity) also play crucial roles in four aspects (Nicole, 2016) which can be described as following:

\subsection{The Uniqueness}

The packaging shape helps the product distinctive from other brands. There is a myriad of product available for consumers to choose; hence, the attractiveness of product packaging is counted as the key aspect in influencing a consumer's decision making. In order to draw consumers' attention, the product has to be interesting and outstanding as well as different from the competitors. The Cannon Blast proposed by Captain Morgan, for example, is designed in an exotic container which is shaped like a cannonball. This distinction promotes higher popularity among its competitors due to a unique characteristic of the product packaging.

\subsection{The Attractiveness}

The packaging color can impact consumers purchase habits. The colors used in product packaging play a key role in consumer buying decisions. Basically, different persons react to colors in different ways; therefore, selecting packaging color is normally processed through a designer's critical thinking in order to provide packaging color which corresponds to interest and demand of the target consumer. Color experts suggest that the more colors added to a product package, the less sophisticated the product is. In other words, colors basically deliver some messages (e.g., white refers to purity or innocence, light sky blue color is counted as more playful, or dark navy is considered much more professional) as well as represent the identity of the product (i.e., the concepts behind a product or target consumer perceptions). Thus, the color of product packaging can effect consumer's product interpretation as well as purchase determination.

\subsection{The Marketing Tool}

The product packaging logo can be a helpful marketing tool through advertising. Branded products are easily recognized, so designing packaging with the striking logo helps consumers remember the product when they are shopping next time. The outstanding logo effectively supports the cohesiveness between the product and the brand as well as simultaneously boosts attracting attention and creating an impression of consumers. This means that the more the packaging logo can be recalled, the more the product reaches larger consumers.

\subsection{The Brand Recognition}

The packaging identity offers brand recognition. When consumers spend time to think about some of their favorite products, they all have one memorable brand in common. The dominant product packaging which successfully presents its product identity can make consumers continuously stay with the brand. For instance, brands like Coke have made minor changes to their packaging, and stayed their original look over the past 
decades under the slogan that the recognizable brands should not change a thing. The transformation of the product packaging can sometimes ruin the band. As noticed, many successful brands that changed their identity including logo, colors or packaging have to confront with the circulation from consumers after making a big change.

\section{Research Objectives}

1. To investigate the needs toward product packaging of the farmer housewife group in Maha Sawat, Nakhon Pathom province.

2. To develop the product packaging design of the farmer housewife group in Maha Sawat, Nakhon Pathom province.

3. To test the product-package market from consumers of the farmer housewife group in Maha Sawat, Nakhon Pathom province.

\section{The Scope of the Study}

This study on developing the product packaging design was based on these following extents:

1. The packaging design for containing the OTOP product of the Maha Sawat farmer housewife group was conducted on the Thai rice crackers (Kao Tung) packaging.

2. The population in analyzing needs toward the product packaging of the Maha Sawat farmer housewife group consisted of the farmer housewife group as well as the consumers who purchase the products of the farmer housewife group in Maha Sawat.

3. The sample involving the analysis of the needs toward the product packaging of the farmer housewife group in Maha Sawat in Nakhon Pathom province included ten participants comprising five farmer housewives as well as five consumers who purchase the products of the Maha Sawat farmer housewife group. The sample was collected data by employing the focus group discussion method using the interview format regarding needs toward the product packaging.

4. Five printing and product design experts including the teachers in academic institutions and specialists in printing and product design organizations were responsible for evaluating the prototype of the developed product packaging by using the five-likert-scale questionnaire.

5. The population in testing market included the consumers of the OTOP products of the farmer housewife group in Maha Sawat in Nakhon Pathom province.

6. The sample for the market test consisted of two hundred consumers targeted by the accidental sampling. These participants were surveyed the satisfaction towards the OTOP products of the farmer housewife group in Maha Sawat using the five-likert-scale questionnaire based on the conceptual framework proposed by Best (1977).

7. Variables in the Study

7.1) Independent variables were the OTOP product packaging and the farmer housewife group in Maha Sawat in Nakhon Pathom province.

7.2) Dependent variable was a result of the market test on consumers' satisfaction towards the OTOP product packaging of the farmer housewife group in Maha Sawat in Nakhon Pathom province.

\section{Research Hypothesis}

The results of the market test on the customer satisfaction towards consuming the OTOP packaging of the Maha Sawat farmer housewife group based on consumers' gender and age are different. 


\section{Conceptual Framework}

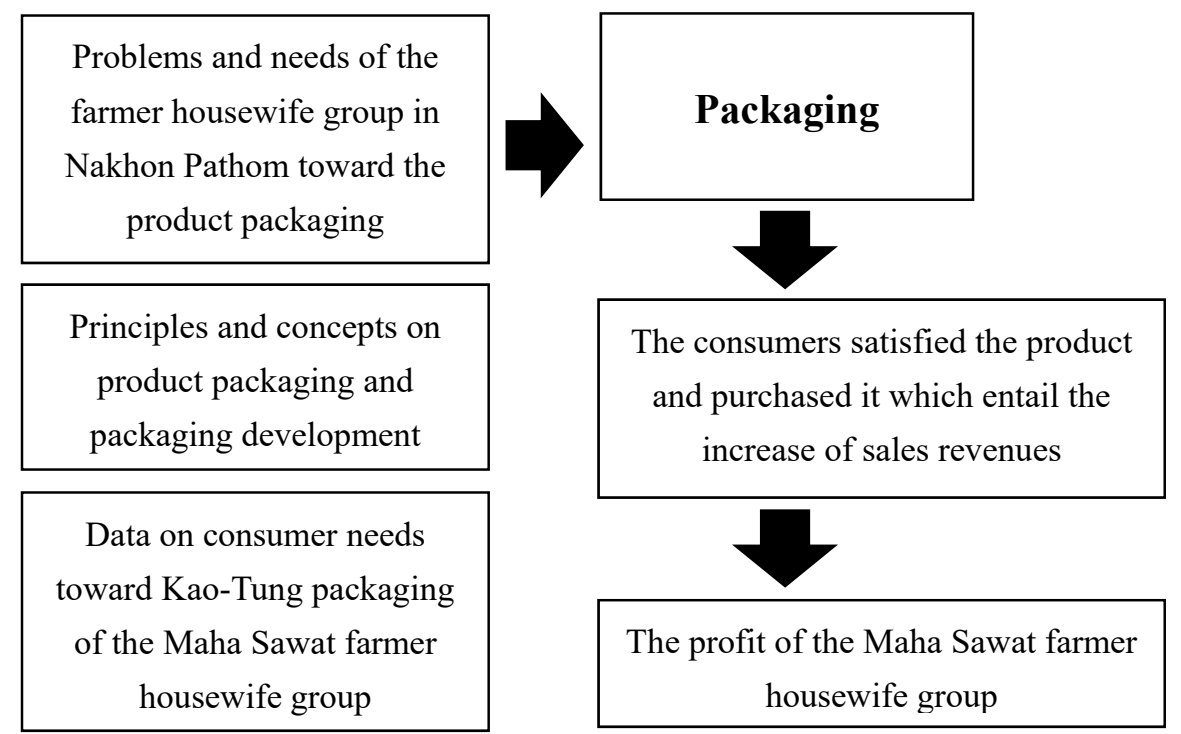

Figure 2. The conceptual framework

\section{Research Methodology}

The research methodology was adapted from the packaging design processes proposed by Pun and Somporn (1998) as well as Jam and Co Design (2017) which could be explained as the following procedures:

1. The researchers reviewed literature and relevant studies to gain the background knowledge and information for constructing the conceptual framework, and understanding data from investigating needs toward product packaging of the farmer housewife group in Maha Sawat, Nakhon Pathom province.

2. The researchers conducted a fieldwork and interviewed participants to gather data by relying on the conceptual framework.

3. The researchers analyzed the data from the documents, interviewing experts and fieldwork information in order to decide the concept of product packaging design.

4. The researchers designed packaging prototype based on the framework of packaging prototype design.

5. The researchers provided a questionnaire to five printing and packaging experts to evaluate their satisfaction towards the developed packaging prototype.

6. The researchers adjusted the packaging by following the experts' suggestions, and provided the five-likert-scale questionnaire to two hundred consumers who were buying the OTOP products of the farmer housewife group in Maha Sawat in Nakhon Pathom province though accidental sampling in order to evaluate the satisfaction towards the adjusted packaging. The consumer satisfaction aspects were classified based on sample's gender and age. This was due to the fact that most consumers were a group of family which normally varied in gender and age. Hence, categorizng the consumer satisfaction based on gender and age could clearer investgate whether the consumer satisfaction aspects were different.

7. The researchers concluded the evaluation result, discussed as well as presented the packaging design.

\section{Results}

The results of the study were separated into 3 sections including:

\subsection{The Results of Investigating Needs toward Product Packaging of the Farmer Housewife Group in Maha Sawat}

After the researchers conducted the fieldwork to do the focus group discussion on the needs toward the product packaging design of ten participants including five farmer housewife group as well as five consumers in order to overcome the problems they confronted (e.g., shelf-life extension, outdated shape of package and the fragility of package), the needs were exhibited as following:

1) The Maha Sawat farmer housewife group required the product packaging to have specific qualifications, such 
as a capacity to extend the shelf life of the product, to keep and reopen next time, as well as to protect the product from fragility while packing. Moreover, the group also needed the packaging label which could provide comprehensible descriptions, the logo which could represent the group identity, and the packaging which could increase the product circulation.

2) The consumers of the Maha Sawat farmer housewife group had requirements on the packaging beauty which could promote the interestedness of the product, the packaging portability which consumers could carry with them, the packaging capacity which was suitable for containing both sauce and Kao Tung, the packaging label which informed necessary product descriptions, and the packaging maintaining ability which helped the consumers keep and reopen the product next time.

\subsection{The Results of Developing Product Packaging of the Maha Sawat Farmer Housewife Group}

After the researchers followed the research processes, the results of analyzing needs about the product packaging and applying into the packaging design demonstrated as followed:

1) After the researchers applied all gathered needs into developing Kao Tung packaging, the result was illustrated in Figure 3. During the development, the created packaging prototype was evaluated by the experts and revealed a high level of all criteria as shown in Table 1.
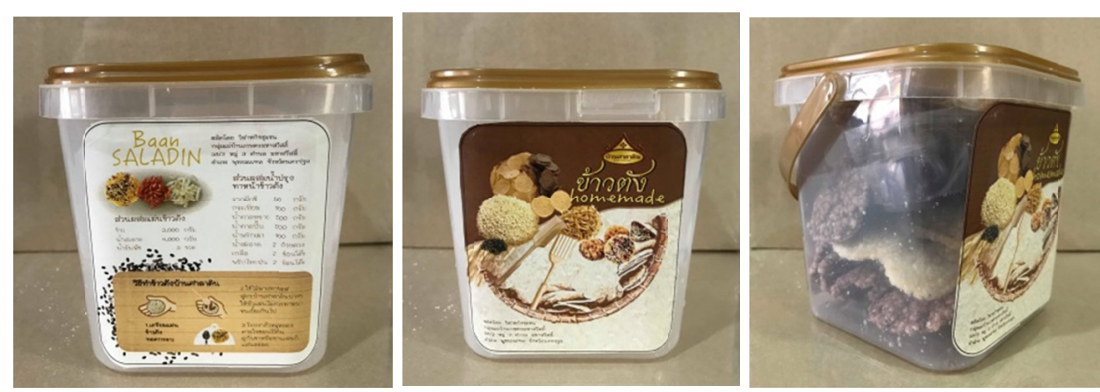

Figure 3. The Kao Tung packaging

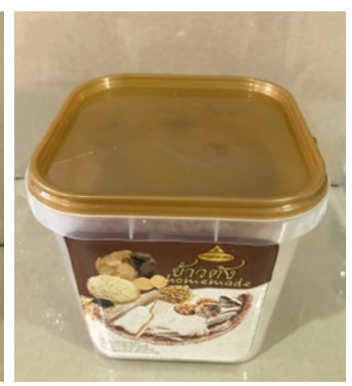

Table 1. The Experts' opinions towards the OTOP product packaging design of the farmer housewife group in Maha Sawat in Nakhon Pathom province

\begin{tabular}{lccc}
\hline \multicolumn{1}{c}{ Lists of Evaluation Criterion } & Mean & S.D. & $\begin{array}{c}\text { Level of } \\
\text { Satisfaction }\end{array}$ \\
\hline 1. The suitability of containing the product of the packaging & 4.40 & 0.49 & High \\
2. The ability in protecting and maintaining the product & 4.20 & 0.40 & High \\
3. The appropriateness of the materials used & 4.40 & 0.49 & High \\
4. The convenience of usability & 4.00 & 0.00 & High \\
5. The remarkableness and beauty of the shape & 4.20 & 0.40 & High \\
6. Logo & 4.20 & 0.40 & High \\
7. Colors & 4.00 & 0.00 & High \\
8. Fonts & 4.20 & 0.40 & High \\
9. Graphic pattern & 4.40 & 0.49 & High \\
10. Illustrations & 4.20 & 0.40 & High \\
11. The remarkableness and attractiveness of the packaging on a shelf & 4.60 & 0.49 & Highest \\
12. The ability in representing the identity of the product and producer & 4.20 & 0.40 & High \\
13. The ability in informing information to consumers & 4.20 & 0.40 & High \\
14. The ability in increasing the value of the product & 4.20 & 0.40 & High \\
Total & 4.24 & 0.43 & High \\
\hline
\end{tabular}


8.3 The Results of the Market Test Conducted on the Consumers of the farmer housewife group in Maha Sawat in Nakhon Pathom province

The result of adjusting the packaging by following the experts' advice and using the questionnaire to survey satisfaction of 200 consumers who were classified by their gender and age found that regarding classification by gender, there were 107 male consumers (53.5\%) and 93 female consumers $(46.5 \%)$. There were 7 consumers aged 16-30 (3.5\%), 67 consumers aged 30-45 (33.5), 103 consumers aged 45-60 (51.5\%) as well as 23 consumers aged 60 and upper (11.5\%) for classification by age. These results were illustrated in Table 2 and 3 as followed:

Table 2. The Consumers' satisfaction towards the Kao Tung packaging of the Maha Sawat farmer housewife group

\begin{tabular}{lccc}
\hline \multicolumn{1}{c}{ Lists of Evaluation Criterion } & Mean & S.D. & $\begin{array}{c}\text { Level of } \\
\text { Satisfaction }\end{array}$ \\
\hline 1. The suitability of containing the product of the packaging & 4.33 & 0.52 & High \\
2. The ability in protecting and maintaining the product & 4.49 & 0.54 & High \\
3. The appropriateness of the materials used & 4.32 & 0.54 & High \\
4. The convenience of portability & 4.49 & 0.55 & High \\
5. The remarkableness and beauty of the shape & 4.26 & 0.49 & High \\
6. Logo & 4.45 & 0.58 & High \\
7. Colors & 4.42 & 0.59 & High \\
8. Fonts & 4.36 & 0.60 & High \\
9. Graphic pattern & 4.32 & 0.51 & High \\
10. The remarkableness and attractiveness of the packaging on a shelf & 4.41 & 0.53 & High \\
11. The ability in representing the identity of the product and producer & 4.41 & 0.55 & High \\
12. The ability in informing information to consumers & 4.35 & 0.56 & High \\
Total & 4.38 & 0.55 & High \\
\hline
\end{tabular}

According to the Table 2, the Kao Tung packaging of the farmer housewife group in Maha Sawat in Nakhon Pathom province had the average of the overall aspects at 4.38 and the standard deviation with 0.55 . The highest level came from both the ability in protecting and maintaining the product as well as the convenience of portability as evidenced by the average of 4.49 and the standard deviation with 0.55 .

The result of comparing the consumers' satisfaction towards the Kao Tung packaging of the Maha Sawat farmer housewife group was elucidated in Table 3.

Table 3. The comparison of the consumers' satisfaction towards the Kao Tung packaging of the Maha Sawat farmer housewife group based on gender and age

\begin{tabular}{|c|c|c|c|c|c|}
\hline Factors Influencing the Consumers' Satisfaction & ss & $\mathrm{df}$ & Ms & $\mathrm{F}$ & $\mathrm{p}$ \\
\hline \multicolumn{6}{|l|}{ Gender } \\
\hline Between Groups & 6.386 & 23 & \multirow{3}{*}{$\begin{array}{l}.278 \\
.246\end{array}$} & \multirow{3}{*}{1.127} & \multirow{3}{*}{.321} \\
\hline Within Groups & 43.369 & 176 & & & \\
\hline Total & 49.755 & 199 & & & \\
\hline \multicolumn{6}{|l|}{ Age } \\
\hline Between Groups & 12.377 & 23 & \multirow{3}{*}{$\begin{array}{l}.538 \\
.505\end{array}$} & \multirow{3}{*}{1.066} & \multirow{3}{*}{.387} \\
\hline Within Groups & 88.803 & 176 & & & \\
\hline Total & 101.180 & 199 & & & \\
\hline
\end{tabular}


It was presented in the Table 3 that the factors which influence the consumers' satisfaction towards the Kao Tung packaging of the Maha Sawat farmer housewife group based on gender and age in overall aspects were insignificantly different having the $\mathrm{p}$ value higher than .05 .

\section{Conclusion}

The Maha Sawat farmer housewife group and the consumers needed the product packaging to have a capacity to extend shelf life of the product, to keep and reopen next time, as well as to protect the product from fragility while packing. Additionally, they also required the beautiful and interesting logo which could represent the group identity, the packaging size which was portable as well as the packaging label could show understandable information.

The market test on the consumers' satisfaction towards the product packaging of the Maha Sawat farmer housewife group had the average at 4.38 and the standard deviation with 0.55 . The result of the market test on the customers' satisfaction towards consuming the OTOP packaging of the Maha Sawat farmer housewife group based on consumers' gender and age demonstrated the insignificant difference in all aspects.

\section{Discussion}

The graphic pattern on the Kao Tung packaging was beautiful and attractive when it was arranged on a shelf which made the evaluation results of the experts were in a high level. Since the graphic and packaging design was remarkable and attractive when the product was on a shelf, the customers' decision to purchase the Kao Tung was promoted. This corresponded with the research of Juthamas (2015) that the prominence and beauty of the graphic design on the packaging of mixing mangosteen extract soap could draw consumers' attention. When the researcher put the soap with other products (both the same product type and different product types) on a shelf, the developed packaging could be outstanding by itself. This could attract consumers' attention since most of the old-version products were packed in plastic bag as well as attached logo that was assimilated to other goods.

Conforming to the results of analyzing factors influencing the consumers' satisfaction towards purchasing the Kao Tung, there was the highest level of factors on both the ability in protecting and maintaining the product as well as the convenience of portability. It meant that these aspects could affect the purchase decision of consumers which was in accordance with Siripan and Taksaya (2016) in analyzing factors which impacted the consumers' determination on buying sallacca wallichiana powder that the factors involving sallacca-wallichiana-powder purchase decision were packing as well as continence. Due to the fact that the old packaging was a vaccum sealer bag, purchasing this product caused difficulty in carrying. This was initially solved by using plastic bag which unavoidably increased the product capital as well as waste. Therefore, developing packaging to be portable could get rid of the problem as well as entail a good satisfaction.

The overall aspects of developing the Kao Tung packaging of Maha Sawat farmers housewife group elucidated a high level of experts' evaluation and satisfaction results due to the fact that there was a consideration on strong points of the current product, such as the remarkableness of characteristics and logo, the ability in extending Kao Tung shelf life which could keep and reopen next time with the storage container lid, necessary-desciption provision as well as the portable ability which could solve the plastic problems on both product-capital increase and environmental destruction. This was consistent with the claim of Herbert \& Bud (2010) that a good packaging could benefit on security, maintenance, value increase, continence of usability as well as being environmental friendly. Furthermore, it was accordingly with Bo (2009, pp 988-1002) who proposed the research on packaging design: creating competitive advantage with product packaging that the external and internal factors of the product influenced the design of the packaging in order to promote customers buying decision. Besides, it also corresponded to Rosjana (2017) that the packaging brand and logo design as well as understandable information provision were necessary to the marketing since those could lead consumers' attention as well as purchase determination.

The drawback of product packaging development in this study related to the capacity in containing Kao Tung. If the researchers needed to contain Kao Tung equally to the old-version packaging, the size of the new packaging had to be bigger. Moreover, using the bigger packaging size caused too much product capital or maintaining the profit needed increasing the sale price which may consequently make the consumers refused to purchase the product. Hence, the researchers decided to reduce the packaging size, which the new packaging size had to be similar to the old version as much as possible, in order to decrease the product capital as well as avoid impact on the product price. 


\section{Suggestion}

1) The packaging of the further study should be designed to be able to protect damage from transportation by cooperating with experts in the related fields.

2) The future research should compare about the product circulation between before and after product packaging development in order to provide more information for designing packaging of other products of the farmer housewife group.

\section{Acknowledgements}

The researchers would like to express his gratitude to Suan Sunandha Rajabhat University for helping us in terms of financial assistance. With all the mentioned supports, the research on the development of OTOP product packaging of Maha Sawat farmer housewife group, Nakhon Pathom province, Thailand was successfully completed on schedule.

\section{References}

Best, J. W. (1977). Research in Education (3rd ed.). New Jersey : Prentice Hall, Inc.

Bo, R. (2009). Packaging design: creating competitive advantage with product packaging. British Food Journal, 111(9), 988-1002. https://doi.org/10.1108/00070700910992880

Herbert, S., \& Bud, T. (2010). A critical overview of the packaging development process. Retrieved from http://www.tappi.org/content/events/10PLACE/papers/schueneman.pdf

Jam, \& Co Design. (2017). 7 step packaging design process. Retrieved from $\mathrm{http} / / /$ jamandco.com.au/7-step-packaging-design-process/

Juthamas, J. (2015). The design and development of packaging for mixing mangosteen extract soap of faculty of science and technology, Rajamangala University of Technology Thanyaburi. RMUTP Research Journal Special Issue the 5th Rajamangala University of Technology National Conference (pp. 28-42). Bangkok Thailand: Rajamangala University of Technology Phra Nakhon.

Nicole, R. (2016). 4 Reasons Why Product Packaging Is Important. Retrieved from https://retailminded.com/4-reasons-why-product-packaging-is-important/

Pun, K., \& Somporn, K. (1998). Food Product Packaging. Bangkok: Packmate.

Rosjana, C. (2017). The Community-Enterprise Trademark and Packaging Design in Ban Dung District in Udonthani, Thailand. Asian Social Science, 13(11), 59-70. https://doi.org/10.5539/ass.v13n11p59

Sam, A. E. (2018). Packaging Effects on Marketing. Retrieved from http://smallbusiness.chron.com/packaging-effects-marketing-61726.html

Siripan, D., \& Taksaya S. (2016). Guideline to Develop Products and Packaging of Sallacca Wallichiana Powder of Samed Phi Sri Farm Women Group Association, Chanthaburi Province. Retrieved from http://www.ex-mba.buu.ac.th/ACADEMIC/Poster2015/ poster003.pdf

\section{Copyrights}

Copyright for this article is retained by the author(s), with first publication rights granted to the journal.

This is an open-access article distributed under the terms and conditions of the Creative Commons Attribution license (http://creativecommons.org/licenses/by/4.0/). 